
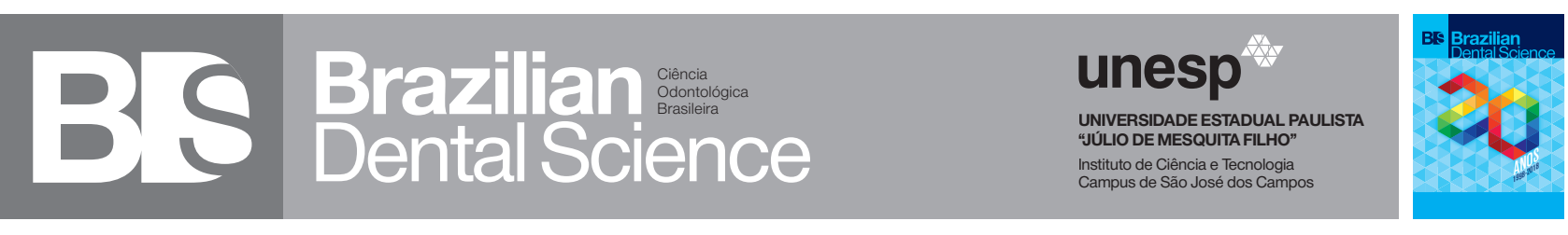

\title{
Intrusion of upper molars with mini-implants for open bite correction is effective? A systematic review
}

A intrusão de molares superiores com mini-implantes para correção da mordida aberta é eficaz? Revisão sistemática

Ana de Lourdes Sá de LIRA ${ }^{1}$, Gustavo Pinho NASCIMENTO ${ }^{1}$, Tennesse Felipe Costa FREITAS ${ }^{1}$

1 - Universidade Estadual do Piauí - UESPI - School of Dentistry - Department of Clinical Dentistry - Area of Integrated Clinic - Parnaíba - PI - Brazil.

\begin{abstract}
Introduction: The open bite is a malocclusion defined by the absence of a positive vertical overlap of the upper incisors over the lower ones. It is believed that the correction of this malocclusion with mini-implants is as effective as another technique. Objective: To verify by scientific evidence the effectiveness of upper molar intrusion with mini-implants for correction of open bite. Material and Methods: This systematic review was conducted according to the PRISMA guidelines. Cochrane Handbook for Systematic Reviews of Interventions (version 5.3) was used to assess the methodological quality and risk of bias of the included studies. Results: During the selection and evaluation process, 795 of the 1297 papers were eligible for research in their titles and abstracts. Repeated articles were removed and as a result, 21 articles were retrieved and read completely. Those who did not meet the inclusion criteria were excluded, resulting in only 6 articles that were included. Conclusion: The intrusion of the upper molars with the use of mini-implants as a skeletal anchor is effective for open bite correction. When the technique of upper molar intrusion with mini-implants was compared with the technique of posterior high pull and incisor extrusion, the first one was more effective for the correction of open bite. The recurrence of molar intrusion does not invalidate mini-implant treatment for open bite correction because the benefits achieved outweigh the small dental relapse.
\end{abstract}

\section{KEYWORDS}

Orthodontics, corrective; Tooth intrusion; Open bite.

\section{RESUMO}

Introdução: A mordida aberta é uma má oclusão definida pela ausência de um trespasse vertical positivo dos incisivos superiores sobre os inferiores. Acredita-se que a correção desta má oclusão com mini-implantes seja tão eficaz quanto outra técnica. Objetivo: Constatar por evidências científicas a eficácia da intrusão dos molares superiores com mini-implantes para correção da mordida aberta. Material e Métodos: Esta revisão sistemática foi conduzida de acordo com as diretrizes PRISMA. Para avaliar a qualidade metodológica e o risco de viés dos estudos incluídos, utilizou-se a Ferramenta Cochrane de Colaboração para avaliação do risco de viés, publicado Cochrane Handbook for Systematic Reviews of Interventions (versão 5.3). Resultados: Durante o processo de seleção e avaliação, 795 dos 1297 artigos mostraram-se elegíveis para a pesquisa em seus títulos e resumos. Os artigos repetidos foram removidos e como resultado, 21 artigos foram recuperados e lidos por completo. Aqueles que não preencheram os critérios de inclusão foram excluídos, resultando em apenas 6 artigos que foram inclusos. Conclusão: A intrusão dos molares superiores com o uso de mini-implantes como ancoragem esquelética é eficaz para correção de mordida aberta. Quando a técnica de intrusão de molares superiores com miniimplantes foi comparada com a técnica de puxada alta posterior e extrusão de incisivos, a primeira foi mais eficaz para correção da mordida aberta. A recidiva da intrusão dos molares não invalida o tratamento com mini-implantes para correção da mordida aberta porque os benefícios alcançados superam a pequena recidiva dentária.

\section{PALAVRAS-CHAVE}

Ortodontia corretiva; Intrusão dentária; Mordida aberta. 


\section{INTRODUCTION}

$\mathrm{T}$ he anterior open bite (MAA) is one of the vertical occlusions that most concern the orthodontic clinic. We can define it as the absence of a positive vertical overjet of the upper incisors on the inferior ones (overbite) [1]. This malocclusion causes great impairment in the masticatory function and in the phonation by hindering the seizure and the cut of foods and the pronunciation of some phonemes. In addition, it may impair aesthetics and affect self-esteem, which justifies its correction [2].

Its etiology may be related to changes in normal breathing patterns, dental ankylosis, incomplete eruption of the anterior teeth, permanence of an infant swallowing pattern and presence of deleterious or non-nutritive oral habits, such as digital sucking or pacifiers. In addition, an unfavorable pattern of maxillary posterior dento-alveolar growth, with vertical predominance, may favor the development of this malocclusion $[2,3]$.

Therapeutic approaches are numerous such as: myotherapy, preventive treatment, functional therapy, orthognathic surgery and orthodontic treatment with the intrusion of the posterior teeth or extrusion of the anterior teeth [4]. Among the non-surgical methods of orthodontic treatment are temporary anchoring devices, including mini -plates and mini-implants [5-7]. However, the extrusion of the anterior teeth demands greater care with the aesthetic smile and is a less stable treatment than the intrusion of the posterior teeth [8].

The use of temporary anchorage devices for intrusion of posterior superior teeth was suggested to decrease the height of the lower third of the face by favoring the mandibular rotation counterclockwise, with results similar to that obtained with orthognathic surgery $[4,5]$.

Dental intrusion is one of the most difficult orthodontic movements to perform, especially in the case of posterior teeth with greater root volume [9]. The greatest challenge is to obtain pure intrusive movement, avoiding the extrusive effect of the anchoring tooth, and thus solving the extrusion of one without causing that of the other. However, with advancement in orthodontics and dentistry as a whole, this obstacle can be overcome by using skeletal anchorage, using miniature titanium plates or mini-implants. This type of anchoring allows dental movement to occur without undesirable effects and without patient dependence and, therefore, with more predictable results [10-12].

It is believed that the correction of MAA with mini-implants is effective as another technique, but with the advantage of not requiring patient collaboration and orthognathic surgery. Thus, the objective of this systematic review was to verify by scientific evidence the effectiveness of upper molar intrusion with mini-implants for correction of open bite.

\section{METHOD}

The systematic review was conducted according to the PRISMA guidelines (www. prisma-statement.org). Independent searches were conducted in the following databases: PubMed, MedLine EBSCO, CAPES Periodicals, SciELO, LILACS, BVS and Scopus, searching for articles published between 2000 and 2017. The search strategy included combinations of keywords, following the syntax rules of each database (Table 1). 
Table 1- Database, search method and number of articles retrieved.

\begin{tabular}{|c|c|c|c|}
\hline & Research strategy & Results & Selected \\
\hline PubMed & $\begin{array}{l}\text { (Maxillary molar intrusion using mini-implants) OR (Maxillary molar intrusion using minis- } \\
\text { crews) OR (Open bite treatment AND Maxillary molar intrusion using mini-implants) OR } \\
\text { (Open bite treatmeant AND Maxillary molar intrusion using miniscrews) }\end{array}$ & 188 & 12 \\
\hline Medline EBSCO & $\begin{array}{l}\text { (Maxillary molar intrusion using mini-implants) OR (Maxillary molar intrusion using minis- } \\
\text { crews) OR (Open bite treatment AND Maxillary molar intrusion using mini-implants) OR } \\
\text { (Open bite treatmeant AND Maxillary molar intrusion using miniscrews) }\end{array}$ & 101 & 9 \\
\hline Periódicos CAPES & $\begin{array}{l}\text { (Maxillary molar intrusion using mini-implants) OR (Maxillary molar intrusion using minis- } \\
\text { crews) OR (Open bite treatment AND Maxillary molar intrusion using mini-implants) OR } \\
\text { (Open bite treatmeant AND Maxillary molar intrusion using miniscrews) }\end{array}$ & 846 & 22 \\
\hline SciELO & $\begin{array}{l}\text { (Maxillary molar intrusion using mini-implants) OR (Maxillary molar intrusion using minis- } \\
\text { crews) OR (Open bite treatment AND Maxillary molar intrusion using mini-implants) OR } \\
\text { (Open bite treatmeant AND Maxillary molar intrusion using miniscrews) }\end{array}$ & 0 & 0 \\
\hline LILACS & $\begin{array}{l}\text { (Maxillary molar intrusion using mini-implants) OR (Maxillary molar intrusion using minis- } \\
\text { crews) OR (Open bite treatment AND Maxillary molar intrusion using mini-implants) OR } \\
\text { (Open bite treatmeant AND Maxillary molar intrusion using miniscrews) }\end{array}$ & 7 & 1 \\
\hline BVS & $\begin{array}{l}\text { (Maxillary molar intrusion using mini-implants) OR (Maxillary molar intrusion using minis- } \\
\text { crews) OR (Open bite treatment AND Maxillary molar intrusion using mini-implants) OR } \\
\text { (Open bite treatmeant AND Maxillary molar intrusion using miniscrews) }\end{array}$ & 46 & 6 \\
\hline Scopus & $\begin{array}{l}\text { (Maxillary molar intrusion using mini-implants) OR (Maxillary molar intrusion using minis- } \\
\text { crews) OR (Open bite treatment AND Maxillary molar intrusion using mini-implants) OR } \\
\text { (Open bite treatmeant AND Maxillary molar intrusion using miniscrews) }\end{array}$ & 109 & 12 \\
\hline & Total articles retrieved & 1297 & 62 \\
\hline & Total without repetition & & 21 \\
\hline
\end{tabular}

The articles were selected based on the title and abstract, with inclusion criteria: upper molar and open bite ( $\mathrm{P}$ - participant) extrusion patients who used mini - implants for upper molar intrusion (I - intervention). The articles also had to compare individuals of the same age and gender treated with another method of intrusion ( $\mathrm{C}$ - comparison), establishing from the results whether the use of mini - implants for upper molar intrusion is more effective than the use of another method or there is no difference between the techniques ( $\mathrm{O}$ result) (Table 2). Exclusions were: literature review, editorial or personal opinions, clinical case reports, studies with individuals in the deciduous dentition, mixed or those who had prolonged use of systemic medication and / or systemic disorder or who underwent surgery for correction of the open bite.

The selection of articles was performed by two investigators based on critical analyzes of inclusion and exclusion criteria and the level of agreement according to the Kappa scores was 0.96 intra-examiner and 0.95 inter-examiner. If there were discrepancies found between the two researchers, a new researcher would be added to evaluate the articles. When there was a consensus among reviewers for articles that met the inclusion criteria, the article would eventually be included in the systematic review.

Table 2 - Inclusion criteria based on PICO format.

\begin{tabular}{|c|c|}
\hline & Inclusion criteria \\
\hline $\mathbf{P}$ (participants) & $\begin{array}{l}\text { Patients with open bite and maxillary molar ex- } \\
\text { trusion }\end{array}$ \\
\hline I(intervention) & They used mini-implants for upper molar intrusion \\
\hline C(comparison) & $\begin{array}{l}\text { Individuals of the same age and gender treated } \\
\text { with another intrusion method }\end{array}$ \\
\hline O(outcomes) & $\begin{array}{c}\text { Hypothesis: better effectiveness in molar intrusion } \\
\text { with mini-implants than any other method. Null } \\
\text { hypothesis: There is no difference between the } \\
\text { techniques. }\end{array}$ \\
\hline
\end{tabular}


The initial analysis excluded articles with titles and abstracts that were not related to the issue studied and that presented at least one of the exclusion criteria. The next step was a detailed analysis of the selected articles to examine those who met all the inclusion criteria or presented exclusion criteria. When the information in the title or abstract was insufficient to decide on inclusion or exclusion, the full article was read and then decided about its inclusion or exclusion. Articles without abstract have been read entirely to define their eligibility.

To assess the methodological quality and risk of bias of the included studies, the Cochrane Collaboration Tool for bias risk assessment was used, published Cochrane Handbook for
Systematic Reviews of Interventions (version 5.3) [13].

\section{RESULTS}

During the first step of the selection and evaluation process, 795 of the 1297 papers were eligible for research in their titles and abstracts. For the removal of the repeated articles, the result of the PubMed search database was compared with the other study participants. As a result, 21 articles were retrieved and read completely. Those who did not meet the inclusion criteria were excluded from the survey. Finally, only 6 articles were included in this systematic review (Figure 1).

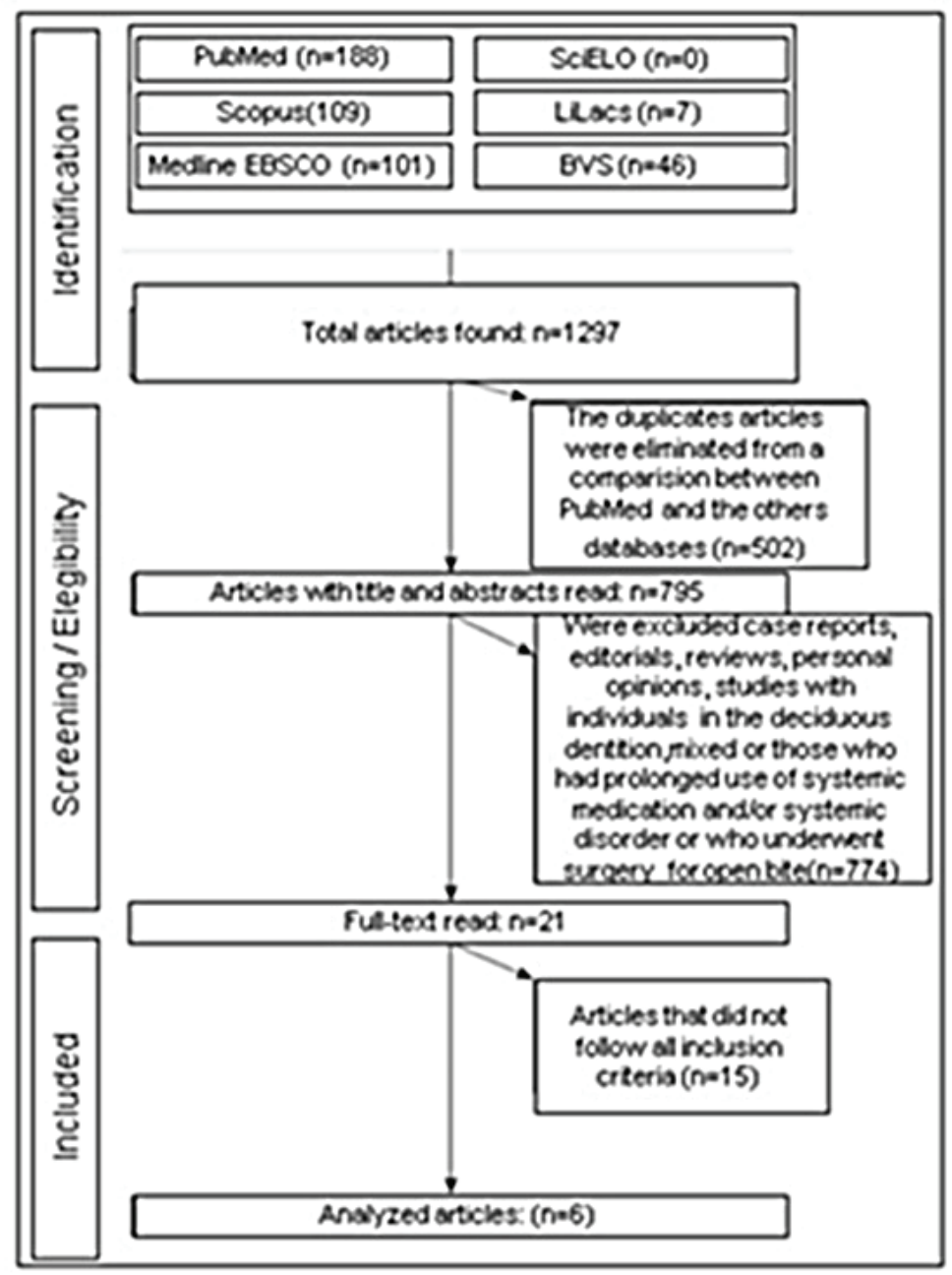

Figure 1- Flowchart: search results. 
After submission of articles [14-19] in the Cochrane Collaboration tool for assessing bias risk (version 5.3), published in the Cochrane Handbook for Systematic Reviews of
Interventions, two studies were classified as low risk of bias [14,19], and the other four [15-18] as high risk of bias (Figure 2).
BAEK et $\mathrm{al}^{14}, 2010$

DEGUCHI et al ${ }^{15}, 2011$

LEE et $\mathrm{al}^{16}, 2013$

Foot et $\mathrm{al}^{17}, 2014$

Scheffler et $\mathrm{al}^{18}, 2014$

Hart et al ${ }^{19}, 2015$
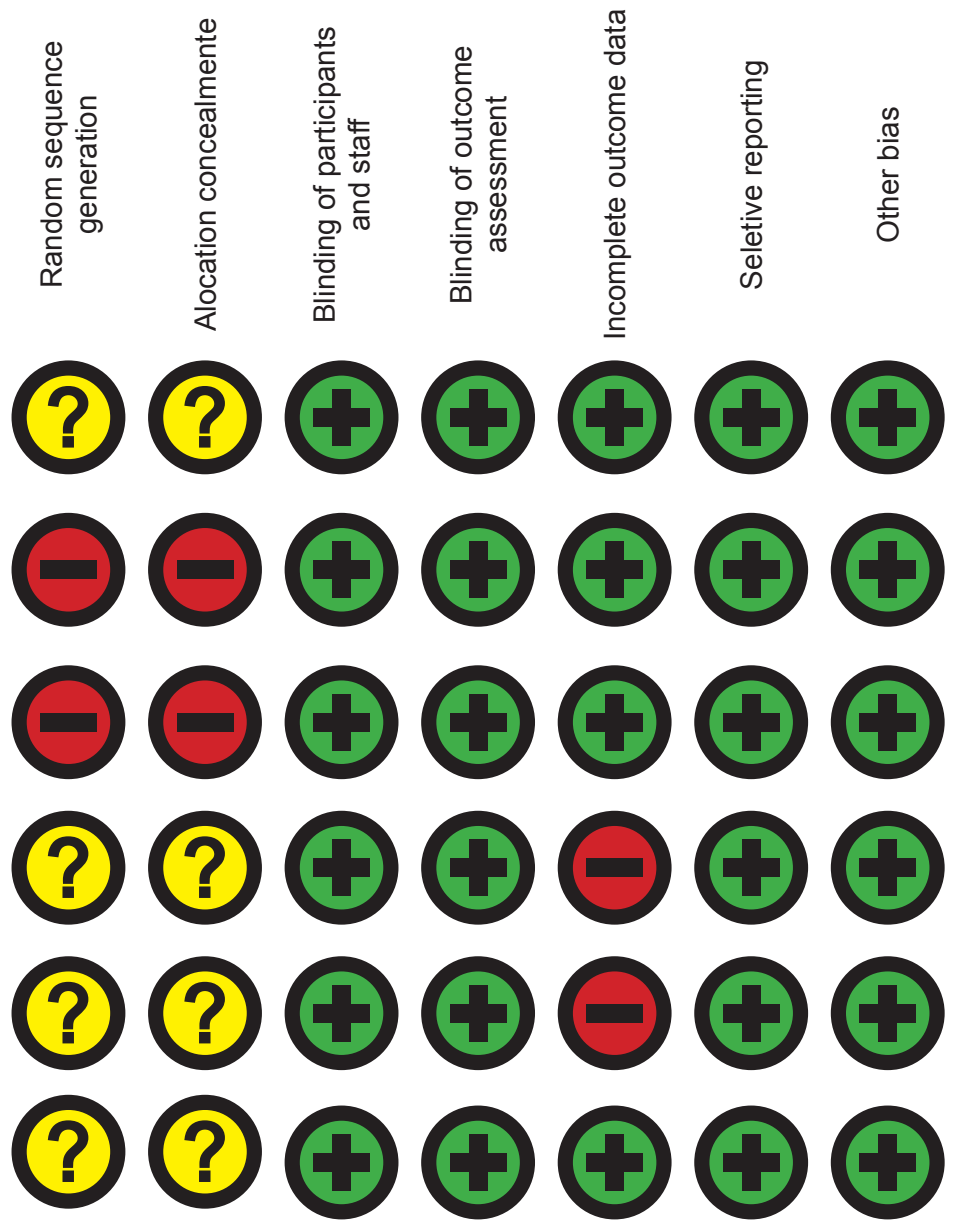

Figure 2 - Qualitative evaluation of the selected studies. (Cochrane Collaboration Tool to Assess Bias Risk)

In the questions "random sequence generation" and "allocation concealment", two of the articles $[15,16]$ were considered as high bias because they did not use random method to select the sample or even how participants were selected for the groups to be compared. The other four articles were classified as risk of uncertain bias because they did not clearly describe whether some random method was used to select the sample and because they presented a single participant group.
Due to the use of different devices and orthodontic treatments used, "blindness of participants and staff" was not possible in any of the studies evaluated. However, there was no high risk of bias in these criteria since knowledge of the treatment technique would not change the outcome. Low risk of bias was attributed to "blindness of outcome assessment" in all studies.

With regard to "incomplete outcomes data", two papers presented a high risk of bias. In the first [17], the authors reported that one 
of the participants lost the mini-implant and in the second [18] three participants abandoned the study, being classified with high risk of bias. The other articles [14-16,19] were classified as low risk of bias. Regarding the items "selective reporting" and "other bias", all articles were considered low risk.

Table 3 shows the data extracted from the articles: author, year, age, sample size and characteristics, treatment performed, results and $\mathrm{p}$ value. The number of participants in the studies ranged from 9 to 31 . All the studies used the mini-implant as an anchorage for intrusion, being analyzed by cephalometric radiographs, but only two $[15,16]$ compared or associated with another technique. In this systematic review, Deguchi et al. [15] and Lee et al. [16] concluded that upper molar intrusion was more efficient in patients using mini-implants than in patients who used another method. The studies by Baek et al. [14] and Scheffler et al. [18] concluded that the amount of intrusion of the super-posterior teeth was greater than the relapse observed 3 and 2 years after treatment, respectively.

Table 1- Description of included studies.

\begin{tabular}{|c|c|c|c|c|c|c|}
\hline \multirow[t]{2}{*}{ Author } & \multicolumn{2}{|c|}{ Participants } & \multirow[t]{2}{*}{$\begin{array}{l}\text { Characteristics } \\
\text { of the sample }\end{array}$} & \multirow{2}{*}{$\begin{array}{c}\text { Intervention } \\
\text { Type of treatment }\end{array}$} & \multirow[t]{2}{*}{ Results } & \multirow[t]{2}{*}{$p$-value } \\
\hline & Total & Age & & & & \\
\hline $\begin{array}{l}\text { Baek et al } \\
\text { [14] (2010) }\end{array}$ & $9(8 \mathrm{~F} / 1 \mathrm{M})$ & $\begin{array}{l}23.7 \text { (be- } \\
\text { tween } 18.3 \\
\text { and 31.1) }\end{array}$ & $\begin{array}{l}\text { MAA average } \\
\quad>3.91 \\
\text { High mandibular } \\
\text { plane SN-MP>40 }\end{array}$ & $\begin{array}{l}2 \text { mini-implants between the } \\
10 \text { s and } 20 \text { s molars ( } 1 \text { on each } \\
\text { side) in the buccal ridge for } \\
5.4 \pm 2.4 \text { months and conten- } \\
\text { tion } 41 \pm 5 \text { months) }\end{array}$ & $\begin{array}{l}\text { Intrusion of the maxillary molars } 2.39 \mathrm{~mm} \text { in avera- } \\
\text { ge compared to the palatal plane with an average } \\
\text { overbite of } 1.65 \mathrm{~mm} \text {. There was an average recur- } \\
\text { rence of molar intrusion of } 0.41 \mathrm{~mm} \text { and overbite of } \\
1.2 \mathrm{~mm} \text { after } 3 \text { years of treatment }\end{array}$ & $<0.05$ \\
\hline \multirow[b]{2}{*}{$\begin{array}{l}\text { Deguchi etal } \\
\text { [15](2011) }\end{array}$} & $15(\mathrm{~F})$ & $22.9 \pm 4.9$ & MAA 4.6mm \pm 1.5 & $\begin{array}{l}\text { Extraoral High pull, extruded } \\
\text { incisors and intermaxillary } \\
\text { elastic }\end{array}$ & $\begin{array}{l}\text { Increased intrusion of the maxillary molars with } \\
\text { mini-implants }\end{array}$ & $<0.05$ \\
\hline & $15(\mathrm{~F})$ & $25.7 \pm 6.4$ & $\mathrm{MAA} 4.4 \mathrm{~mm} \pm 1.2$ & $\begin{array}{l}2 \text { mini-implants between } \\
\text { the } 10 \text { s and } 20 \text { s molar or } \\
\text { between } 2^{\circ} \text { premolar and } 1^{\circ} \\
\text { molar in the alveolar process } \\
\text { by vestibular }\end{array}$ & $\begin{array}{l}\text { Increased intrusion of the maxillary molars with } \\
\text { mini-implants }\end{array}$ & $<0.05$ \\
\hline \multirow{2}{*}{$\begin{array}{l}\text { Lee et al [16] } \\
\quad(2013)\end{array}$} & $\begin{array}{c}28 \\
(6 \mathrm{M} / 22 \mathrm{~F})\end{array}$ & $19.6 \pm 7.3$ & $M A A \geq 2 \mathrm{~mm}$ & $\begin{array}{l}\text { Extraoral High pull of } 250 \mathrm{~g} / \\
\text { f; transpalatal arch; interma- } \\
\text { xillary elastic }\end{array}$ & The maxillary molars were intruded $0.71 \mathrm{~mm}$ & $<0.001$ \\
\hline & 23(M) & $21.5 \pm 6.19$ & $M A A \geq 2 m m$ & $\begin{array}{l}2 \text { mini-implants in the medial } \\
\text { palatal suture } 2 \times 6 \mathrm{~mm}\end{array}$ & The maxillary molars were intruded $1.30 \mathrm{~mm}$ & $<0.001$ \\
\hline $\begin{array}{l}\text { Footetal } \\
\text { [17](2014) }\end{array}$ & $16(12 F / 4 M)$ & $\begin{array}{l}\text { 13.1(be- } \\
\text { tween } 12.2 \\
\text { and 14.3) }\end{array}$ & $M A A \geq 2 m m$ & $\begin{array}{l}4 \text { mini-implants in the pos- } \\
\text { terior region of the maxilla } \\
\text { in the alveolar process by } \\
\text { vestibular ( } 2 \text { on each side) } \\
500 \mathrm{~g} / \mathrm{f} \text { and continuous arc } \\
0.017 \times 0.025 \mathrm{~mm}\end{array}$ & $\begin{array}{l}\text { Intrusion of maxillary molars } 2.9 \pm 0.8 \mathrm{~mm} \\
\text { Overbite increased } 3 \pm 1.5 \mathrm{~mm}\end{array}$ & $<0.001$ \\
\hline $\begin{array}{l}\text { Scheffler et } \\
\text { al [18] (2014) }\end{array}$ & $\begin{array}{c}30 \\
(11 \mathrm{M} / 19 \mathrm{~F})\end{array}$ & $24.1 \pm 10.7$ & $\begin{array}{l}\text { MAA }-.2 m m \pm 1.7 \\
\text { High mandibular } \\
\text { plane }\end{array}$ & $\begin{array}{l}2 \text { mini-implants between } 10 \text { s } \\
\text { e } 20 \text { s molars (10n each side) } \\
\text { in the alveolar process by } \\
\text { vestibular }\end{array}$ & $\begin{array}{c}\text { Intrusion of maxillary molars } 2.3 \mathrm{~mm} \text { in average. } \\
\text { Decrease of facial height in average of } 1.6 \mathrm{~mm} \text {. } \\
\text { There was an average recurrence of molar intru- } \\
\text { sion of } 0.2 \mathrm{~mm} \text { and facial height of } 0.5 \mathrm{~mm} \text { after } 2 \\
\text { years of treatment }\end{array}$ & $<0.05$ \\
\hline $\begin{array}{l}\text { Hart et al [19] } \\
\quad(2015)\end{array}$ & $\begin{array}{c}31 \\
(21 \mathrm{~F} / 10 \mathrm{M})\end{array}$ & $\begin{array}{l}\text { 20.7(be- } \\
\text { tween } 11.6 \\
\text { and } 55 \\
\text { years) }\end{array}$ & MAA & $\begin{array}{l}2 \text { mini-implants between } 10 \text { s } \\
\text { e } 20 \text { s molars ( } 1 \text { on each side) } \\
\text { in the alveolar process by } \\
\text { palatine }\end{array}$ & $\begin{array}{l}\text { Intrusion of the upper molars by } 90 \% \text { ( } 28 \text { of } 31 \text { ) } \\
\text { and } 74 \% \text { ( } 23 \text { of } 31 \text { ) respectively. The molars } 2.3 \mathrm{~mm} \\
\text { and } 20 \text { molars } 1.6 \mathrm{~mm} \text { on average }\end{array}$ & $<0.001$ \\
\hline
\end{tabular}




\section{DISCUSSION}

In many orthodontic treatments, proper anchor planning is imperative for the success of the proposed therapy. Dental intrusion, either for the correction of excessive overbite or anterior open bite, or for the correction of extruded teeth by the lack of antagonists, represents a great mechanical challenge due to the difficulty of controlling undesirable movements in the anchoring units. Obviously, over the years, the literature has indicated satisfactory results with the use of extra auxiliary devices and intraoral. However, it is not always easy to obtain from the patient the necessary collaboration, the physical and / or aesthetic discomfort that these devices can cause [20].

In this context, an excellent alternative is the use of mini-implants. Its development, over the last few years, has provided a very efficient anchorage, which eliminates the use of teeth and does not entail any aesthetic compromise, nor does it require any patient collaboration $[20,21]$.

This resource has been used more and more frequently in the orthodontic clinic when there are not enough dental units to promote effective anchoring or simply to make the mechanics less complex and more predictable for the orthodontist [21].

In the six studies there was no sample calculation, and the sample selection was performed within the inclusion criteria of each study, as mentioned in the sample characteristic topic in Table 3. Five studies were based in clinical records of treated patients, with the exception of the Foot et al. [17] study whose patients were selected to be treated after the approval of the ethics committee.

Regarding the statistical analysis, Lee et al. [16] and Foot et al. [17] used the t test, Baek et al. [14] used ANOVA and Pearson correlation coefficients. Deguchi et al. [15] selected MannWhitney and Wilcoxon tests, Scheffler et al. [18], an autoregressive correlation test and Hart et al. [19] used Pearson correlation coefficients.
In order to verify the long-term stability of maxillary posterior teeth intrusion using miniimplants aiming at the open bite correction, Baek et al. [14] carried out a study with 9 participants $(1 \mathrm{M} / 8 \mathrm{~F})$ in 2010 . As a technique for molar intrusion, two mini-implants were used between the first and second molars (one on each side), a technique similar to that used by Scheffler et al. [18] in 2014. The miniimplants were used for $5.4 \pm 2.4$ months for intrusion. Thereafter, the participant group used palatal restraint for $41 \pm 5$ months. The authors performed four cephalometric evaluations: before treatment (T1), after treatment (T2), one year after treatment (T3) and three years after treatment (T4). Comparing the obtained data it was possible to observe that the average overbite of the patients in T1 went from -3.91 $\mathrm{mm}$ to 1.65 after the treatment. Three years after the treatment (T4), there was recurrence in the overbite of $1.2 \mathrm{~mm}$, and in the molar intrusion of $0.41 \mathrm{~mm}$. Even so, they concluded that favorable dentoskeletal changes were achieved, and the benefits achieved outweighed the small dental relapse. Thus, the use of miniimplants for molar intrusion in the correction of open bite is effective, corroborating with the opinion of other authors $[5,10,18]$.

Like Baek et al. [14] in 2010, Hart et al. [19] in 2015, also used the cephalometric exam to evaluate the dentoskeletal changes achieved with the intrusion of the posterior maxillary teeth, using mini-implants as an anchorage. Their group was 31 participants $(21 \mathrm{~F} / 10 \mathrm{M})$, aged 18.3 to 31.1 years. Two mini-implants between the first and second molars were inserted through the palatine, where they remained intruded for 5.4 \pm 2.4 (months). Cephalometric examinations were performed prior to initiation of treatment and after completion for comparison. The most significant data showed dental intrusion of the first molars (mean $2.39 \mathrm{~mm}$ in $90 \%$ of patients) and second molars (mean of $1.65 \mathrm{~mm}$ in $77 \%$ of patients). Post-treatment extrusion was also observed, but, like other authors [10,14,18], concluded that orthodontic mini-implants provide adequate skeletal anchorage for the 
postero-superior molar intrusion in MA patients with overbite of patients improved in $97 \%$ of treated cases.

In their study, Lee et al. [16] in 2013, tested two methods for upper molar intrusion. The 28 participants of group A $(6 \mathrm{M} / 22 \mathrm{~F})$, with a mean age of $19.6 \pm 7.3$, received the extra oral high pull associated with the palatal arch and the intermaxillary elastic arch, while group B, composed of $23(\mathrm{M})$ participants with a mean age of $21.5 \pm 6.19$, received two mini-implants in the medial palatine suture. The two groups had MAA $\geq 2 \mathrm{~mm}$. Group A reached, on average, $0.71 \mathrm{~mm}$ of molar intrusion, while in group B the molars intruded $1.30 \mathrm{~mm}$, on average. There were $0.59 \mathrm{~mm}$ of difference between the two methods that corroborate with other studies $[14,19-23]$ on the effectiveness of the intrusion obtained with mini-implants for MA correction.

Deguchi et al. [15], in 2011, also performed a comparative study such as Lee et al. [16], differentiating by the fact that the miniimplants were placed in the alveolar process by vestibular, emphasizing greater intrusion of the upper molars in the group that used miniimplants, but without measuring it.

Foot et al. [17] in 2014 and Hart et al. [19] in 2015, even though they did not present a control group, found approximate values of intrusion of the maxillary molars with mini-implants in the alveolar process by vestibular, even though they diverged in the amount used. The efficacy of upper molar intrusion in MA treatment also was observed in other studies [1-6,9,14,15,18,23,24], who found approximate values.

In the maxilla, on the option of intrusion of the posterior teeth instead of extruding the anterior teeth, some authors [4,8,24,25] stated that intrusion is a more stable and simple movement to achieve, promoting the dentoskeletal changes necessary for the correction of BAD. In other studies $[4,5,19]$ the authors were unanimous in affirming that the result obtained in the treatment of MMA with the use of mini-implants resembles the results obtained with orthognathic surgery.

\section{CONCLUSION}

Intrusion of the upper molars with the use of mini-implants as a skeletal anchor is effective for correction of open bite.

When the technique of upper molar intrusion with mini-implants was compared with the technique of posterior high pull and incisor extrusion, the first one was more effective for the correction of open bite.

The recurrence of molar intrusion does not invalidate mini-implant treatment for open bite correction because the benefits achieved outweigh the small dental relapse.

\section{REFERENCES}

1. Mohammed AAI-L, Sakhr AM, Fuad LA, Mohammed MAI-M. Upper Molar Intrusion with Mini-implants to Correct Anterior Skeletal Open Bite: A Case Report. J Int Oral Health. 2016;8(12):1132-5.

2. Farret MMB, Farret MM. Retratamento de mordida aberta esquelética com intrusão dos molares superiores com mini-implantes. Rev Clín Ortodon Dental Press. 2013Fev/Mar;12(1):61-9.

3. Salguero AEM, Valverde AS. Correction of a skeletal anterior open bite with mini-screws and a modified bite block. Revista Mexicana de Ortodoncia. 2017 Apr-June,5(2):e102-10.

4. Paik $\mathrm{CH}, \mathrm{McComb}$ R, Hong C. Diferential molar intrusion with skeletal anchorage in open-bite treatment. J Clin Orthod. 2016 May;50(5):276-89.

5. Park HS, Kwon OW, Sung JH. Nonextraction treatment of an open bite with microscrew implant anchorage. Am J Orthod Dentofacial Orthop. 2006 Sep;130(3):391-402.

6. Janson G, Laranjeira V, Rizzo M, Garib D. Posterior tooth angulations in patients with anterior open bite and normal occlusion. Am J Orthod Dentofac Orthop. 2016;150(1):71-7. doi: 10.1016/j.ajodo.2015.12.016.

7. Sodagar A, Sobouti F, Shahsavari N. Occlusal plane flattening by miniscrew in skeletal open bite: a case report. Caspian J Dent Res. 2014;3(2):54-9.

8. Kook YA, Park JH, Kim Y, Ahn CS, Bayome M. Orthodontic Treatment of Skeletal Class II Adolescent with Anterior Open Bite using Mini-Screws and Modified Palatal Anchorage Plate. J Clin Pediatr Dent. 2015 Winter;39(2):187-92.

9. Giancotti A, Germano F,Muzzi F, Greco M. A mini-screw supported intrusion auxiliary for open-bite treatment with invisalign. JClin Orthod. 2014 Jun;48(6):348-58.

10. ValarelliFP,Celi MVR, Chiqueto KFG, Freitas KMS, Valarelli DP.Effectiveness of mini-implants in upper molar intrusion. Innov Implant J.2010 Jan/Apr;5(1): 66-71.

11. Sherwood KH, Burch JG, Thompson WJ. Closing anterior open bites by intruding molars with titanium miniplate anchorage. Am JOrthod Dentofacial Orthop. 2002 Dec;122(6):593-600.

12. Alsafadi AS, Alabdullah MM, Saltaji H, Abdo A, Youssef M. Effect of molar intrusion with temporary anchorage devices in patients with anterior open bite: a systematic review. Prog Orthod. 2016;17:9. doi: 10.1186/s40510-016-01224. Epub2016 Mar 23. 
13. Higgins J. Cochrane Handbook for Systematic Reviews of Interventions (Version 5.3).London: Cochrane Collaboration. 2011. [cited 2015 0ct 21]. Available from: http://handbook.cochrane.org/

14. Baek MS, Choi YJ, Yu HS, Lee KJ, Kwak J, Park YC. Long-term stability of anterior open-bite treatment by intrusion of maxillary posterior teeth. Am J Orthod Dentofacial Orthop. 2010 0ct;:138(4):396-405.

15. Deguchi T, KurosakaH, Oikawa H, Kuroda S, Takahashil, Yamashiro T,et al. Comparison of orthodontic treatment outcomes in adults with skeletal open bite between conventional edgewise treatment and implant-anchored orthodontics. Am J Orthod Dentofacial Orthop. 2011 Apr;139(4):60-8.

16. Lee J, Miyazawa K, Tabuchi M, Kawaguchi M, Shibata M, Goto S. Midpalatal miniscrews and high-pull headgear for anteroposterior and vertical anchorage control:Cephalometric comparisons of treatment changes. Am J Orthod Dentofacial Orthop. 2013 Aug;144(2):238-50.

17. FootR, Dalci O, Gonzales C, Tarraf NE, Darendeliler MA. The short-term skeleto-dental effects of a new spring for the intrusion of maxillary posterior teeth in open bite patients. Prog Orthod. 2014 Sep 25;15:56. doi:10.1186/s40510014-0056-7.

18. Scheffler NR, Proffit WR, Phillips C. Outcomes and stability in patients with anterior open bite and long anterior face height treated with temporary anchorage devices and a maxillary intrusion splint. Am J Orthod Dentofacial Orthop. 2014 Nov;146(5):594-602
19. Hart TR, Cousley RRJ, Fishman LS, Tallentes RH.Dentoskeletal changes following mini-implant molar intrusion in anterior open bite patients. Angle Orthodontist. 2015 Nov;85(6):941-8.

20. Araújo TM, Nascimento MHA, Franco FCMF, Bitterncourt MAV. Dental Intrusion Using Mini Implants. RDental Press Ortodon Ortop Facial. 2008 Sep/ 0ct;13(5):36-48.

21. Araújo TM, Nascimento MHA, Bezerra F, Sobral MC. Skeletal anchorage in orthodontics with mini-implants. Rev Dental Press Ortodon Ortop Facial. 2006 Jul/Aug;11(4):126-56.

22. Baumgaertel S, Smuthkochorn S, Palomo JM. Intrusion method for a single overerupted maxillary molar using only palatal mini-implants and partial fixed appliances. Am J Orthod Dentofacial Orthop. 2016 Mar;149(3):411-15.

23. Tseng YC, Hsieh $\mathrm{CH}$, Chen $\mathrm{CH}$, Shen YS, Huang IY, Chen CM. The application of mini-implants for orthodontic anchorage. Int. J. Oral Maxillofac Surg. 2006 Aug;35(8)704-7.

24. Paccini JVC, Cotrim-Ferreira FA, Ferreira FV, Freitas KMS, Cançado RH, Valarelli FP.Efficiency of two protocols for maxillary molar intrusion with mini-implants. Dental Press J Orthod. 2016 May/Jun;21(3):56-66.

25. Artese A, Drummond S, Nascimento JM, Artese F.Criteria for the diagnosis and stable treatment of anterior open bite. Dental Press J Orthod. 2011 May/ Jun;16(3):136-61.

\section{Ana de Lourdes Sá de Lira \\ (Corresponding address)}

Universidade Estadual do Piauí, Faculdade de Odontologia

Rua Senador Joaquim Pires 2076 Ininga.

Fone (86) 999595004

CEP: 64049-590 Teresina-PI-Brasil

email: anadelourdessl@hotmail.com

Date submitted: 2018 Jun 19

Accept submission: 2018 Aug 06 